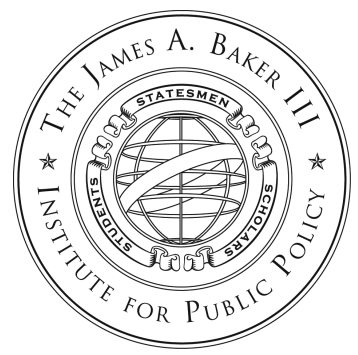

James A. Baker III Institute for Public Policy

RICE UNIVERSITY

\title{
The Political Economy of Arab Gulf States
}

BY

\section{Kristian CoAtes UlRichsen, Ph.D.}

FELLOW FOR THE MIDDLE EAST

JAMES A. BAKER III INSTITUTE FOR PUblic POLICY

RICE UNIVERSITY

MAY 8, 2015 
THIS PAPER WAS WRITTEN BY A RESEARCHER (OR RESEARCHERS) WHO PARTICIPATED IN A BAKER INSTITUTE RESEARCH PROJECT. WHEREVER FEASIBLE, PAPERS ARE REVIEWED BY OUTSIDE EXPERTS BEFORE THEY ARE RELEASED. HOWEVER, THE RESEARCH AND VIEWS EXPRESSED IN THIS PAPER ARE THOSE OF THE INDIVIDUAL RESEARCHER(S) AND DO NOT NECESSARILY REPRESENT THE VIEWS OF THE JAMES A. BAKER III INSTITUTE FOR PUBLIC POLICY.

(c) 2015 by the James A. Baker III Institute for Public Policy of Rice University

THIS MATERIAL MAY BE QUOTED OR REPRODUCED WITHOUT PRIOR PERMISSION, PROVIDED APPROPRIATE CREDIT IS GIVEN TO THE AUTHOR AND

THE JAMES A. BAKER III INSTITUTE FOR PUBLIC POLICY 


\section{Introduction}

This paper assesses the multifaceted reasons behind the Arab Gulf states' uneven record of integration into the global economy. It begins by documenting how the ties binding the Gulf states into the global economy are both deep-rooted and long predate the discovery and extraction of oil in the 20th century. Rather, the opening section highlights the historical interconnectivity of the transnational flows that tied the region into a broader economic hinterland spanning the Indian Oceanic world. Nevertheless, these processes were patchy and subject to partial reversal during the early oil years. Thus, the second section examines the entrenched dynamics that also served to limit the Gulf states' relationship with the international system, both politically and economically. Such dynamics included the conservative leanings of many of the "post-traditional" governing systems in the Arabian Gulf and the Gulf states' enmeshment in Western political and military spheres of influence during this period of prolonged British protection and following the passage to independence.

In the second half of the paper, the focus shifts to the role of energy in framing the function of the Gulf in global economic structures and international trade and investment flows. Beginning in the 1940s, oil exports integrated the Gulf states firmly into the international economic system as Gulf oil became a motor of Western economic growth in the post-World War II era. Securing stable access to regional supplies and the Western guarantees of protection that underpinned this flow of oil to global markets became the pillars that structured the international relations of the Gulf after 1945. Oil from the Gulf, particularly Kuwait, supplied 51 percent of British requirements in 1971, while Saudi Arabia and the United States enjoyed a similarly symbiotic relationship. The paper ends by describing how the Gulf states were only partially impacted by the broader acceleration of economic globalization in the 1970s and 1980s and by the rapid spread of global interconnections in the 1990 s. $^{1}$

\footnotetext{
${ }^{1}$ Anoushiravan Ehteshami, Globalisation and Geopolitics in the Middle East: Old Games, New Rules (London: Routledge, 2007), 110.
} 


\section{An Interregional Crossroad}

By virtue of geographical location, the Arabian and Persian shores of the Gulf and their hinterlands have been an interregional crossroad for centuries. Powerful processes of settlement and exchange tied the area into a cosmopolitan network of interregional trade and migration. Such social and commercial links extend back into antiquity and the pre-Islamic era. In about $2000 \mathrm{BC}$, the island of Failaka, lying just offshore the Kuwaiti coastline, was inhabited by colonists from the Dilmun civilization centred on modern Bahrain, who developed it into a commercial and trading outpost for the entire region. ${ }^{2}$ Later, the Gulf's geographic location astride the meeting point of the Middle East, Africa, and Asia was instrumental in shaping economic development in the region. The lucrative frankincense trade routes that linked Oman and Yemen with the Levant, North Africa, and the Mediterranean were one early example of interregional networks in operation; another example was provided by the dhows and booms that from the 17th and 18th centuries sailed among the Gulf sheikhdoms, the coast of western India, and the port cities of East Africa. Dhows and booms departed each season from Basra and the coastal settlements on both sides of the Gulf to the east coast of Africa and the west coast of India, laden with goods and binding the region to a much broader "transoceanic" maritime community. ${ }^{3}$

In the latter half of the 19th century, important new export markets in Europe and as far away as North America emerged for Gulf dates and pearls. Global demand for both commodities boomed in the later years of the century as international seafaring trade networks proliferated. The value of the date export trade in Muscat (today the capital of Oman) doubled between 1899 and 1906 and increased 2.5 times in Bahrain in the same period. Meanwhile, lifestyle changes and the expansion of the middle and upper classes in industrialized countries generated a substantial

\footnotetext{
${ }^{2}$ D.T. Potts, "The Archaeology and Early History of the Persian Gulf," in The Persian Gulf in History, ed. Lawrence Potter (New York: Palgrave Macmillan, 2009), 30-32.

${ }^{3}$ Thomas Metcalf, Imperial Connections: India in the Indian Ocean Arena, 1860-1920 (Berkeley, CA: University of California Press, 2007), 1.
} 
boom in demand for pearls, as the total value of pearls exported from the Gulf as a whole tripled between 1893 and 1904. ${ }^{4}$ The Kuwaiti historian Fahad Ahmad Bishara has documented how

By the early 20th century, as the boom reached its zenith, the merchants and mariners of the Gulf had established sizeable communities in a number of western Indian ports, including Karachi, Bombay, Goa, and Calicut, with some venturing further into the interior and taking up residence in such trading centers as Hyderabad and Poona. Western India quickly became a cornerstone of the Indian Ocean world of Gulf merchants, providing them with access to foodstuffs such as rice, sugar, tea, and spices, as well as textiles, building materials such as Indian teak, and other types of timber, which were vital to the burgeoning dhow-building industry in the Gulf. ${ }^{5}$

The powerful merchant families of the Hejaz (including the Ali-Rida, Zainal, Shobokshi, and Jamjum) constituted the mainstay of economic power in the Arabian Peninsula, together with immigrant merchants, many of whom came from Hadramawt in Yemen (the Bin Mahfuz, Bin Ladin, Bin Sakr, and Ka'aki families being prominent examples). These early economic elites operated within a broad transnational sphere stretching from East Africa to India and were cosmopolitan in their outlook and connections to international economic interests. In his seminal study of the major Gulf merchant families, Michael Field described how one of the scions of the Alireza family (in modern-day Saudi Arabia), Mohammed Ali, visited Paris for the first time in 1920.

Drawing on the help of business friends, he opened an office at 62 rue La Fayette, on the edge of the main shopping area of Paris...From the early 1920s, Mohamed Ali made it his habit to spend several months at a stretch in Paris each year-he bought a house on

\footnotetext{
${ }^{4}$ Fahad Ahmad Bishara, "Mapping the Indian Ocean World of Gulf Merchants, c.1870-1960," in The Indian Ocean: Oceanic Connections and the Creation of New Societies, eds. Abdul Sheriff and Engseng Ho (London: Hurst \& Co, 2014), 78-79.

${ }^{5}$ Ibid, 79.
} 
the Champs Elysees...During the height of his career in pearls, he lived almost permanently in Bombay and Paris. ${ }^{6}$

Writing about Bahrain's most prominent merchant family of the 19th century, the Safar, James Onley provides an evocative description of a relentlessly transregional family hailing from Hillah in modern-day Iraq but putting down deep roots across Bahrain, Iran, and India.

...Hajji Mirza Muhammad Ali Safar (1778-1845) was born in Bushehr; lived in Hillah, Mochah, Bahrain, Bushehr, and Bombay; was a Persian, Ottoman, and possibly British Indian subject; wrote his letters in Farsi and Arabic...His brother, Hajji Muhammad Jafar, was born in Bombay to a Persian mother from Shiraz, lived in Bombay and Bushehr, was a British Indian subject, dressed in the style of an Indian merchant in Bombay, and probably spoke Farsi, Arabic, and Hindi. ${ }^{7}$

Such movement (and opportunity) was restricted to elites and was not generally available to the majority of the inhabitants of the Arabian Peninsula. However, in addition to the intermixing of merchant elites and economic migrants, tribal movements were also fluid as allegiances and relationships shifted over time and in response to localized factors. ${ }^{8}$ A case in point was the movement of large numbers of people as a result of the collapse of the pearling economy in the Gulf in the aftermath of the Great Depression in 1929 and the Japanese introduction of cultured pearls. Socioeconomic hardship and conditions of near-famine caused more than one-third of the population of Qatar at the time to migrate to neighboring states in search for work and sustenance. $^{9}$

\footnotetext{
${ }^{6}$ Michael Field, The Merchants: The Big Business Families of Saudi Arabia and the Gulf States (Woodstock, NY: The Overlook Press, 1985), 24.

${ }^{7}$ James Onley, "Transnational Merchants in the Nineteenth Century: the Case of the Safar Family," in Transnational Connections and the Arab Gulf, ed. Madawi al-Rasheed (Abingdon: Routledge, 2005), 68-69.

${ }^{8}$ James Onley and Sulayman Khalaf, "Shaikhly Authority in the Pre-oil Gulf: An Historical-Anthropological Study," History and Anthropology 17, no. 3 (2006): 191.

9 Jill Crystal, Oil and Politics in the Gulf: Rulers and Merchants in Kuwait and Qatar (Cambridge: Cambridge University Press, 1990), 5.
} 


\section{Countervailing Forces of Conservatism}

The intermixing of peoples and cultures described above had a strong influence on the emergent states and societies in the Gulf. This rich geographical history belies any notion of the region as peripheral to world history in the pre-oil era or any attempt to define the Gulf solely by possession of some of the largest energy reserves in the world. Nevertheless, the integration of the coastal Arabian Peninsula sheikhdoms into the network of British protectorates between 1835 and 1916 profoundly influenced the region's subsequent political development. Beginning with the signing of a General Treaty of Peace in 1820 and a "perpetual" Maritime Truce in 1835 and motivated by imperial considerations of safeguarding the coastal flanks of the maritime route to India, British officials representing the (British-controlled) Government of India concluded individual treaties with the Trucial States (now the United Arab Emirates) in 1835, Bahrain in 1861, Kuwait in 1899 and again in 1914, and Qatar in 1916. Together, the agreements enmeshed the emerging proto-state entities into an inward-oriented, sub-regional unit in which British "protection" was extended in return for exclusive political and economic relations. ${ }^{10}$

British protection elevated and formalized the roles of the ruling families in each sheikhdom, as Lisa Anderson documented in her important article on the "resilience of monarchy" in the Middle East in 1991. This external protection additionally gave ruling elites in the Arabian Peninsula-whether members of the ruling families or the British political officers-a considerable stake in maintaining the conservative status quo. A prime example of this conservatism in practice occurred in Kuwait in 1938, where the powers of the ruler, Sheikh Ahmad al-Jabir Al-Sabah, were threatened by a vigorous reform movement that culminated in the election of a Legislative Council in June of that year. Under the leadership of a senior member of the ruling family, Sheikh Abdullah al-Salim Al-Sabah (himself a future ruler of Kuwait between 1950 and 1965), the new body immediately involved itself in the administrative and financial governance of Kuwait and made unprecedented demands on the ruler's power. Most notably, the council forced Sheikh Ahmad al-Jabir to consent to Article One of the law that established the council, which stipulated that the people were the source of power as represented

\footnotetext{
${ }^{10}$ James Onley, "Britain and the Gulf Shaikhdoms, 1820-1971: The Politics of Protection," Occasional Paper No.4, Georgetown School of Foreign Service in Qatar (2009), 10.
} 
by elected members of the Legislative Council. ${ }^{11}$ However, when these developments inspired similar reform movements in Dubai and Bahrain, they began to alarm British officials as much as the ruler himself. With power seemingly slipping away from the carefully constructed group of British-protected sheikhs up and down the Gulf, Britain supported Sheikh Ahmad al-Jabir when he dissolved the council in December 1938 and suppressed its elected replacement in March 1939. ${ }^{12}$

A slightly different set of circumstances prevailed in Oman and Saudi Arabia although the end result was broadly similar. In Oman, British influence was informal yet pervasive-as opposed to Oman's formal establishment of protectorate relations with Kuwait, Qatar, and Bahrain-yet it maintained a determined grip over the regime of Sultan bin Taimur (ruled 1932-1970). ${ }^{13}$ British officials in the early decades of the 20th century also sought to build relationships among the competing claimants of power in the Hejaz and Nejd. However, Britain's backing of the sharif of Mecca during and after the Arab Revolt during World War I failed eventually to prevent the Hashemite leader from being defeated decisively by Ibn Saud (Abdulaziz bin Abdulrahman AlSaud) in 1925. The expansion of Ibn Saud's rule across the Arabian Peninsula culminated in the creation of the modern Kingdom of Saudi Arabia in 1932 and the subsequent development of close relations with the United States. In February 1943, President Franklin Delano Roosevelt declared that the defense of Saudi Arabia was vital to American security, following a series of long-distance Italian bombing raids against oil installations in Saudi Arabia and Bahrain, and his administration designated Saudi Arabia eligible for Lend Lease assistance. Two years later, on Valentine's Day 1945 and shortly before his death, Roosevelt journeyed from the Yalta Conference to the Great Bitter Lake in Egypt for the fabled meeting with Ibn Saud that has formed the cornerstone of the "oil for security" bargain between the United States and Saudi Arabia ever since. ${ }^{14}$

\footnotetext{
${ }^{11}$ Kamal Osman Salih, "The 1938 Kuwait Legislative Council,” Middle Eastern Studies 38, no. 1 (1992): 77.

${ }^{12}$ Mary Ann Tetreault, "Autonomy, Necessity, and the Small State: Ruling Kuwait in the Twentieth Century," International Organization 45, no. 4 (1991): 577.

${ }^{13}$ Michael Herb, All in the Family: Absolutism, Revolution, and Democracy in the Middle Eastern Monarchies (Albany, NY: State University of New York Press, 1999), 147.

${ }^{14}$ Joel Migdal, Shifting Sands: the United States in the Middle East (New York: Columbia University Press, 2014), 3.
} 
During this period before and after World War II, British officials scrambled to protect their political allies in the smaller coastal sheikhdoms who were otherwise vulnerable to Saudi expansionism to the peripheries of the Arabian Peninsula. After 1945, the growing web of political and military ties between Saudi Arabia and the United States constituted a new strategic challenge to Britain's regional primacy. Initially British officials tried to resist the growth of American influence in the Gulf, only to come closer together in the early 1950s as the shared sense of Cold War threat increasingly preoccupied American and British attention. However, differences in approach remained a factor in regional policymaking, particularly toward Yemen. ${ }^{15}$ While the gradual transition from British to American influence was far from seamless and unfolded over a period of four decades from the 1940s to the 1980s, the Western political and security umbrella did provide shelter for Saudi Arabia and the smaller Gulf states and buffered their rulers from the political crosscurrents of Arab nationalism and socialism. ${ }^{16}$

Although not monolithic in political structure and capable of including progressive political leaders such as the "Free Princes" and Abdullah al-Tariki (the "Red Sheikh" and the co-founder of the Organization of Petroleum Exporting Countries [OPEC]) in Saudi Arabia, the Gulf regimes nevertheless developed a reputation for political caution as they transitioned into fully fledged independent states. This contrasted sharply with popular and radical movements of national liberation among post-colonial entities elsewhere in the world between the 1940s and 1960s, and it required the Gulf rulers to adopt a delicate — and at times awkward — balancing act between their reliance on British protection and the need to appease politicized local groups within society. ${ }^{17}$ Nevertheless, the pragmatic pursuance of strategies of survival enabled the ruling families to manage quite effectively the transformational socioeconomic impact of incoming oil revenues on their polities. The capture of such processes of change enabled Gulf rulers to defy the arguments of social scientists such as Karl Deutsch and Samuel Huntingdon, who predicted their imminent demise in the $1950 \mathrm{~s}$ and $1960 \mathrm{~s} .{ }^{18}$

\footnotetext{
15 Jeffrey Macris, The Politics and Security of the Gulf: Anglo-American Hegemony and the Shaping of a Region (Abingdon: Routledge, 2009), 99; W. Taylor Fain, American Ascendance and British Retreat in the Persian Gulf Region (Basingstoke: Palgrave Macmillan, 2008), 133.

${ }^{16}$ Ibid.

${ }^{17}$ Onley, "Britain and the Gulf Shaikhdoms," 18.

${ }^{18}$ Christopher Davidson, The United Arab Emirates: A Study in Survival (London: Lynne Rienner, 2005$), 66$.
} 
Internal and external considerations therefore reinforced a conservative political stance that distinguished the Gulf states from the majority of other developing countries during the postcolonial period following the end of World War II. The divergence in worldviews became clear during the Marxist-supported rebellion in the Omani province of Dhofar from 1965 to 1975. Officials from the People's Democratic Republic of Yemen (PDRY - the only Marxist state ever to exist in the Arab world) supported the Popular Front for the Liberation of Oman and the Arabian Gulf (PFLOAG) in its struggle against the Omani sultanate. Oman eventually defeated the rebellion, but only after high levels of British political and military assistance, including deployment of SAS battalions that extended well beyond Britain's formal military withdrawal from the Gulf on November 30, 1971. Such high levels of external assistance-which also came in the form of Iranian military support provided by the shah - enabled PDRY officials to portray the Dhofar campaign as a "war of liberation against foreign occupation" from the "puppets of colonialism in Oman" and its "client government," propped up by British (and Iranian) assistance. $^{19}$

The Dhofar war and its regional repercussions visibly illustrated the extent of the Gulf states' divergence from political trajectories then dominant in much of the developing world. Moreover, the struggle to prevent the spread of revolutionary Marxism into the neighboring Gulf states was an illustration of how broader Cold War tensions played themselves out on a local scale. By pitting British- and Iranian-backed government forces against rebels armed with Chinese and Soviet weaponry, the campaign demonstrated the interplay among competing local, regional, and international interests in framing the nature of the conflict in the southern flank of the Arabian Peninsula. ${ }^{20}$ The strategy of rolling back any ideological threat to regional stability was made more significant by the failure of Western-led attempts to create a durable security pact that would act as a bulwark against the spread of Communism in the Middle East. Both the shortlived Baghdad Pact (created in 1955 by Britain, Iraq, Iran, Pakistan, and Turkey) and its

\footnotetext{
${ }^{19}$ Letter from the Permanent Representative of the People's Democratic Republic of Yemen to the Secretary General of the United Nations, November 26, 1973, The National Archives, London, file FCO 8/2037.

${ }^{20}$ Odd Arne Westad, The Global Cold War: Third World Interventions and the Making of our Times (Cambridge: Cambridge University Press, 2005), 3.
} 
successor, the Central Treaty Organization (CENTO), foundered after the revolutions that swept away conservative monarchical rule in Iraq in 1958 and Iran in $1979 .{ }^{21}$

This intersection of Gulf states' and Western security interests from the 1950s through the 1970s complicated and delayed the growth of tangible links with the Soviet Union and major emerging economies such as China, which actively supported the anti-imperialist, revolutionary movement in Dhofar and the PDRY. Kuwait was the earliest of the Gulf states to establish diplomatic relations with the Union of Soviet Socialist Republics (USSR) in 1963 and China in $1971 .^{22}$ Until the 1980s, Kuwait was the only regional state to maintain a working political, financial, and military relationship with the USSR, with Saudi Arabia only establishing diplomatic relations with Moscow after the Iraqi invasion of Kuwait in 1990. With China, the normalization of ties did not occur until after Deng Xiaoping announced a moderation of Chinese policies away from the ideological rigidity of the Mao era in 1978, after which Oman established diplomatic relations with China in 1978, followed by the United Arab Emirates (UAE) in 1984, Qatar in 1988, Bahrain in 1989, and Saudi Arabia, again, in $1990 .^{23}$

The bifurcation between the Gulf states and much of the developing world, including other Arab and Islamic states, was reinforced by a Saudi-led policy of actively resisting the political currents sweeping the region in the post-war years. The Al Saud led the way in the 1960s and 1970s in encouraging the formation of Islamic organizations to counter left wing or secular oppositional alternatives. Under King Saud (ruled 1953-64) and King Faisal (ruled 1964-75), Saudi Arabia engaged also in an "Arab Cold War," broadly pitting the region's conservative monarchies against its revolutionary republics led by Egypt's charismatic President Gamal Abdul Nasser as Saudi and Egyptian military forces backed competing proxy factions in Yemen. ${ }^{24}$ Moreover, the inflow of oil revenues into Saudi Arabia facilitated the creation of an array of international Islamic institutions and networks that extended transnationally the kingdom's "soft power." Notable examples were the creation of the Muslim World League in 1962, the Organization of

\footnotetext{
${ }^{21}$ Migdal, Shifting Sands, 54-55.

${ }^{22}$ Abdul-Reda Assiri, Kuwait's Foreign Policy: City-State in World Politics (Boulder, CO: Westview Press, 1990), 26.

${ }^{23}$ Mahmoud Ghafouri, “China's Policy in the Persian Gulf,” Middle East Policy 16, no. 2 (2009): 83.

${ }^{24}$ Fred Halliday, The Middle East in International Relations: Power, Politics, and Ideology (Cambridge: Cambridge University Press, 2005), 122-23.
} 
the Islamic Conference (OIC) and the World Assembly of Muslim Youth in 1972, and the International Islamic Relief Organization (IIRO) in $1975 .^{25}$

\section{The Oil "Revolution"}

The pre-oil economy of the communities distributed along the shoreline of the Gulf was dominated by the pearl industry. Pearling structured social relationships and hierarchies within a segmented labor force broken up into merchant-moneylenders, the ship captains (nakhodas), and the divers and haulers who undertook the dangerous tasks of collecting the pearls from the seabed, and spawned a derivative service economy that supported and sustained it. Not for nothing has the pearl become the heritage symbol of the modern Gulf states, found on banknotes and monuments throughout the region and fondly recalled in heavily sanitized folk histories that usually downplay its harshness, inequalities, and dangers to life and limb. Prior to the discovery of oil in the 1930s and the commencement of exports in the 1940s, pearling constituted the major economic activity for decades, and its sudden demise created conditions of real hardship. This occurred in the space of just a few years after the onset of the Great Depression in 1929, as the international demand for pearls collapsed, while the introduction of Japanese cultured pearls left Gulf producers unable to compete on cost. One chronicler of Qatar described it as "a disaster which almost overnight removed the one export on which the people of the Gulf could rely to bring in foreign earnings." 26

The smaller Gulf states' reliance on a single economic sector for the majority of incoming revenues curiously foreshadowed their later dependence upon oil receipts. Although the pearling and oil industries are completely different in scale, organization, and economic and technopolitical complexity, they both represented volatile streams that fluctuated according to external factors and international demand, both of which were beyond the control of local officials. This was at its most pronounced in Qatar, where the impact of the collapse of the pearling industry was magnified by the near absence of any other form of economic activity, as the country lacked

\footnotetext{
${ }^{25}$ Roger Hardy, "Ambivalent Ally: Saudi Arabia and the 'War on Terror'," in Kingdom without Borders: Saudi Arabia's Political, Religious and Media Frontiers, ed. Madawi al-Rasheed (London: Hurst \& Co., 2008$), 101$.

${ }^{26}$ John Bullock, The Gulf: A Portrait of Kuwait, Qatar, Bahrain and the UAE (London: Century Publishing, 1984), 119.
} 
the entrepôt trade of Kuwait, Bahrain, or Dubai. Qatar's greater dependence on pearling had dramatic results, as Crystal estimates that between one-third and one-half of the population chose to emigrate during the decade that elapsed between the end of the pearl era and the subsequent onset of the oil era. These emigrants included many members of the business class: only two major merchant families - the Darwish and the al-Mani-remained behind. ${ }^{27}$

Oil was first discovered in the Middle East in southwest Persia (modern-day Iran) in 1908 and later was found in commercial quantities in northern Iraq near Kirkuk in 1927. Exploration quickly began in the neighboring Gulf sheikhdoms, where geological conditions were similar to those where oil had been struck in Iran. On May 31, 1932, the newly created Bahrain Petroleum Company (BAPCO), a British-controlled subsidiary of the Standard Oil Company of California (SoCal), struck oil in Bahrain. Production began the following year, and in 1933 SoCal (today's Chevron) was awarded the concession to search for oil in the new Kingdom of Saudi Arabia. ${ }^{28}$ Five years later, oil was discovered in the Dammam Dome in the Eastern Province, near the western shoreline of the Gulf, and following a decade-long interruption due to World War II, large-scale Saudi oil exports commenced in 1948. Government revenues immediately surged from the US\$13-16 million range annually between 1938 and 1946 to US\$53.6 million in 1948 and US\$100 million in $1950 .^{29}$ This required the urgent creation of a system of functional governing ministries, coordinated by the establishment of a Council of Ministers in October 1953, capable of absorbing and spending the incoming monies. This took place in the final weeks of Ibn Saud's life and followed closely on the creation of the Saudi Arabian Monetary Agency (SAMA) as a means of institutionalizing mechanisms of monetary and fiscal control. ${ }^{30}$

\footnotetext{
${ }^{27}$ Crystal, Oil and Politics in the Gulf, 5-6.

${ }^{28}$ Rosemarie Said Zahlan, The Making of the Modern Gulf States (Reading: Ithaca Press, 1998), 26.

${ }^{29}$ Tim Niblock and Monica Malik, The Political Economy of Saudi Arabia (Abingdon: Routledge, 2007 ), 36.

${ }^{30}$ Sarah Yizraeli, The Remaking of Saudi Arabia (Tel Aviv: The Moshe Dayan Center for Middle Eastern and African Studies, 1997), 102-3.
} 


\section{Table 1 - Oil Discoveries in the Gulf States}

Country

Bahrain

Kuwait

Saudi Arabia

Qatar

UAE (Abu Dhabi)

Oman

Dubai
Date

1932

1938

1938

1939

1958

1962 (commercial grade)

\section{Source: Information collated by Kristian Coates Ulrichsen}

Elsewhere in the Gulf events followed a similar pattern, with the exception of the Trucial States (the modern UAE) and Oman, where oil only became a significant factor several decades later. In Kuwait, a concession to explore for oil was granted to the newly formed Kuwait Oil Company (a joint venture founded in 1934 by the Anglo-Persian Oil Company and America's Gulf Oil). Large quantities of oil were located at Burgan in 1938, nine days before the discovery of oil in Saudi Arabia, but, as in Saudi Arabia, full exploration and development was delayed until after 1945. Commercial exports from Kuwait started in June 1946 and production nearly tripled in the first year alone, from 5.9 million barrels in 1946 to more than 16 million barrels in $1947 .^{31}$ Similar conditions pertained in Qatar, where Petroleum Development Qatar Limited-a forerunner of the present state-owned oil company, Qatar Petroleum — was formed in June 1935 by a consortium that included Royal Dutch Shell and the Compagnie Française des Pétroles (today's Total). As in Kuwait and Saudi Arabia, the first oil was found in Qatar in late 1939, but

\footnotetext{
${ }^{31}$ Michael Casey, The History of Kuwait (Westport, CT: Greenwood Press, 2007), 58-59.
} 
further exploration and production came to a halt until the end of the war, whereupon exports began, admittedly at a tiny rate initially, in $1947 .^{32}$

The exploration and extraction of oil in the Trucial States/UAE and Oman occurred later than elsewhere in the Gulf. After several false starts in the 1950s, oil was finally discovered in the emirate of Dubai in the early 1960s, and exports commenced later in the decade. Further discoveries onshore and offshore pushed oil production in Dubai to a peak in 1991, after which production levels began an inexorable and steady decline. ${ }^{33}$ Dubai's reserves paled in comparison to those in neighboring Abu Dhabi, which today accounts for more than 90 percent of total UAE oil reserves. The first oil in Abu Dhabi was located at Umm Shaif in 1958 and the first exports from Das Island occurred in 1962, but production only took off after Sheikh Zayed replaced his brother as ruler of Abu Dhabi in 1966 and set in motion the full development of the emirate's resources. ${ }^{34}$ Similar to Abu Dhabi, the discovery of oil in Oman between 1962 and 1964 had to await political change at the apex of the state, as production remained tiny prior to the replacement of Sultan Taimur bin Said by his son, the present ruler, Sultan Qaboos, in July $1970 .^{35}$

Once production got underway, the level of exports increased rapidly. A case in point is Saudi Arabia, where oil dominated the economy after exports commenced in 1948. By 1959, the sector accounted for 85 percent of government revenues and 90 percent of foreign export earnings, in addition to financing almost all commercial and infrastructural development. ${ }^{36}$ During the subsequent decade, production approximately doubled and revenues tripled from 1962 to 1970, at a time when the posted price of oil remained fixed at US\$1.80. ${ }^{37}$ Similar dynamics were at play in Kuwait, as the country initially became the largest oil producer in the Gulf in the early 1950s. This occurred in part as Kuwait replaced Iran as a major supplier of oil to Western markets after the Iranian government's nationalization of the oil industry in 1951 and a resulting boycott of Iranian oil. In the space of just seven years, Kuwait's oil revenues soared from

\footnotetext{
${ }^{32}$ Matthew Gray, Qatar: Politics and the Challenges of Development (Boulder, CO: Lynne Rienner, 2013 ), $30-32$.

${ }^{33}$ Christopher Davidson, Dubai: The Vulnerability of Success (London: Hurst \& Co, 2008), 100-101.

${ }^{34}$ Christopher Davidson, Abu Dhabi: Oil and Beyond (London: Hurst \& Co, 2009), 50.

${ }^{35}$ Marc Valeri, Oman: Politics and Society in the Qaboos State (London: Hurst \& Co, 2009), $72-73$.

${ }^{36}$ Niblock and Malik, The Political Economy of Saudi Arabia, 36-37.

${ }^{37}$ Ibid, 39.
} 
US\$760,000 in 1946 to US\$169 million in $1953 .{ }^{38}$ By the time of the first oil price boom in 1973, oil revenues had reached US\$9.8 billion and accounted for 70 percent of Kuwait's total gross domestic product (GDP). ${ }^{39}$ Imports also surged, particularly after the 1973 oil price shock created a new class of affluent consumers virtually overnight; the number of registered vehicles in Saudi Arabia, for instance, rose 65-fold between 1970 and 1984 from 60,000 to 3.9 million. $^{40}$

Revenues from the export of oil transformed the socioeconomic structures and development patterns in the Gulf states. At first, the rudimentary traditional patterns of administration that held sway across large parts of the Arabian Peninsula until the 1930s and 1940s were incapable of managing the integration of the young new states into the global oil market. Thus, the challenges involved in absorbing and utilizing enormous sums of money led to the rapid creation of institutional frameworks that often coexisted uneasily alongside the traditional measurements of power and authority, particularly in the early years. ${ }^{41}$ Oil began to be exported in commercial quantities in the late 1940s and production rose rapidly in the 1950s and 1960s. This coincided with the formative passage to independence of Kuwait (1961) and the UAE, Bahrain, and Qatar (1971), and the early processes of modern state formation in Oman and Saudi Arabia.

Particularly after the first oil-price shock of 1973, the resulting surge in government revenues provided the growing state structures with the financial wherewithal to reformulate traditional tribal structures into modern forms of governance. Pete Moore has noted that, as a region, the Middle East and North Africa outperformed all other regions in the developing world with regard to income growth and redistribution in the period between 1960 and $1985 .^{42}$ In the specific context of the Gulf states, the redistributive mechanisms of sociopolitical control that emerged did so within a highly stratified economic framework encompassing nests of rentiers flowing

\footnotetext{
${ }^{38}$ Zahlan, The Making of the Modern Gulf States, 39.

${ }^{39}$ Laura El-Katiri, Bassam Fattouh, and Paul Segal, "Anatomy of an Oil-Based Welfare State: Rent Distribution in Kuwait," in The Transformation of the Gulf: Politics, Economics and the Global Order, eds., David Held and Kristian Ulrichsen (Abingdon: Routledge, 2011), 167.

${ }^{40}$ Pascal Menoret, Joyriding in Riyadh: Oil, Urbanism, and Road Revolt (Cambridge: Cambridge University Press, 2014), 125.

${ }^{41}$ Yizraeli, The Remaking of Saudi Arabia, 184.

${ }^{42}$ Pete Moore, Doing Business in the Middle East: Politics and Economic Crisis in Jordan and Kuwait (Cambridge: Cambridge University Press, 2004), 85.
} 
downward from the state at its apex. ${ }^{43}$ Thus, the impact of oil rents became intertwined from the start with emerging state structures and decisions on how to absorb and utilize the revenues, thereby giving rise to pronounced regional socioeconomic peculiarities. ${ }^{44}$

Over the course of the second half of the 20th century, the flow of oil from the Arabian Peninsula also became a critical component in the growth of the world economy. Table 2 illustrates the magnitude of GCC states' proven crude oil reserves in regional and global comparison and indicates also how small Bahrain's indigenous reserves are by comparison to those of its GCC neighbors (Bahrain's production of 40,000 barrels per day [in 2011 figures] is boosted significantly by the allocation of an additional 150,000 barrels per day from Saudi Arabia's offshore Abu Safa field operated by Saudi Aramco). ${ }^{45}$

\footnotetext{
${ }^{43}$ Giacomo Luciani, The Arab State (London: Routledge, 1990), 69.

${ }^{44}$ Simon Bromley, Rethinking Middle East Politics: State Formation and Development (Cambridge: Polity Press, 1994), 120.

45 "Bahrain-Saudi Arabia Ties Stronger than Ever,” Saudi Gazette, July 28, 2011.
} 


\section{Table 2 - Proven Crude Oil Reserves, 2014}

\begin{tabular}{|c|c|c|}
\hline$\underline{\text { Rank }}$ & Country & Proven Reserves (barrels) \\
\hline 1 & Venezuela & $297,700,000,000$ \\
\hline 2 & Saudi Arabia & $268,400,000,000$ \\
\hline 3 & Canada & $173,200,000,000$ \\
\hline 4 & Iran & $157,300,000,000$ \\
\hline 5 & Iraq & $140,300,000,000$ \\
\hline 6 & Kuwait & $104,000,000,000$ \\
\hline 7 & UAE & $97,800,000,000$ \\
\hline 8 & Russia & $80,000,000,000$ \\
\hline 9 & Libya & $48,470,000,000$ \\
\hline 10 & Nigeria & $37,140,000,000$ \\
\hline 11 & United States & $30,530,000,000$ \\
\hline 13 & Qatar & $25,240,000,000$ \\
\hline 24 & Oman & $5,500,000,000$ \\
\hline 69 & Bahrain & $124,600,000$ \\
\hline
\end{tabular}

Source: CIA World Factbook

Led by the United States and the post-war economies of Western Europe and Japan, industrialized countries embarked upon two decades of economic growth after 1945. With this 
period constituting "the golden age of Middle Eastern exploration," the amount of oil sourced from the Gulf region - encompassing also Iran and Iraq-grew rapidly in both absolute and relative terms. ${ }^{46}$ Indeed, by 1960 , the Gulf states were producing 15 percent of the world's oil and a decade later this figure had approximately doubled to 30 percent. Most remarkably, in the case of the United Kingdom, Britain's dependence on oil from the Middle East (including Algeria) peaked at 81 percent in 1950 (as against 1.5 percent in 2012). ${ }^{47}$ These figures catapulted the commercial and strategic importance of the Gulf region-hitherto expressed largely in terms of the security of the British Empire and the protection of the land and sea routes to British-ruled India - up the agendas of international policymakers. ${ }^{48}$

Gulf oil revenues held an additional importance to the British economy as it struggled to adapt to the post-1945 decline of the United Kingdom. Oil prices for the British-protected states in the Gulf were fixed in sterling and, initially in the 1950s, the majority of imports also came from the United Kingdom as well. The intersection of political and financial ties between Britain and the Gulf states acted as a vital prop to successive British government attempts to maintain the value of sterling. Indeed, by 1959, it was estimated that the value of Gulf assets in the United Kingdom amounted to more than one-quarter of Britain's total gold and foreign exchange holdings. Kuwait, especially, emerged as a vital linchpin in British government efforts to prevent a precipitous decline in sterling. Although the small Gulf states continued to back sterling by holding their surplus oil income in London well into the $1960 \mathrm{~s}$, the situation ended abruptly in 1967 following the 16 percent devaluation of sterling. This hit Gulf foreign assets hard and led to the diversification of the region's foreign holdings and an end to the use of sterling as a major reserve currency. ${ }^{49}$

As oil prices soared following the 1973 Arab-Israeli war and the subsequent Arab oil embargo, so the revenues pouring into Gulf treasuries multiplied. Across the region, oil rents were used to

\footnotetext{
${ }^{46}$ Robin Mills, The Myth of the Oil Crisis (Westport, CT: Praeger Publishers, 2008), 58.

${ }^{47}$ David Roberts, "British National Interest in the Gulf: Rediscovering a Role?," International Affairs 90, no. 3 (2014): 671.

${ }^{48}$ Roger Owen, “One Hundred Years of Middle Eastern Oil,” Brandeis University, Crown Center for Middle East Studies, Middle East Brief No. 24 (January 2008), 1.

${ }^{49}$ Sara Bazoobandi, The Political Economy of the Gulf Sovereign Wealth Funds: A Case Study of Iran, Kuwait, Saudi Arabia and the United Arab Emirates (Abingdon: Routledge, 2013), 38-39.
} 
create an all-encompassing welfare state, as the government became a distributor to, rather than an extractor of wealth from, citizenry. The average price of crude oil surged from US\$2.04 a barrel in 1971 to a high of US\$32.50 in 1981, as the 1973 rise in prices was followed by a second spike in 1979-80 in the wake of the Iranian revolution and the outbreak of the Iran-Iraq war. Simultaneously, the six Gulf states' combined crude oil production rose by 77 percent between 1970 and 1980, resulting in a massive inflow of oil revenues, which increased from US\$5.2 billion to US\$158 billion during the period. ${ }^{50}$ The states entered into a society, however, still characterized by poverty and underdevelopment, with low absorptive and human capacity to manage the sudden wealth and ruling elites prone to commissioning extravagant and wasteful "white elephant" prestige projects. Indeed, during the "freewheeling" decade of the 1970s, almost all of the additional income generated by the oil price increases was spent immediately, rather than being saved for future generations, heightening Gulf states' subsequent vulnerability to the slump in prices to a low of just US\$10 a barrel in $1986 .{ }^{51}$

With the massive influx of incoming revenues into Gulf economies in the 1970s, the flows of oil rents provided the emerging state structures with the financial wherewithal to create redistributive or "rentier" states. Here, the "no taxation without representation" paradigm was seemingly reversed as regimes sought to co-opt sociopolitical support through the spread of wealth and exhibited varying degrees of autonomy from societal demands or pressures. Simultaneously, however, demands for reform also proliferated as oil revenues flooded into Gulf treasuries. In Qatar, this took the form of a petition in 1963 that contained 35 demands for reform. One of the most prominent and vocal advocates of change, Dr. Ali Khalifa al-Kuwari, who worked in Qatar's oil and gas sector as vice chairman of the Qatar Liquefied Gas Company and as vice chairman of the National Company for Petroleum Products before joining Qatar University as a professor of economics, described what happened next:

The background of demands for reform in oil-rich Qatar goes back to the 35 demands of the 1963 petition, the strikes, imprisonments, and expulsions that preceded and

\footnotetext{
${ }^{50}$ Sharon Shochat, "The Gulf Cooperation Council Economies: Diversification and Reform," LSE Kuwait Programme Introductory Paper, 2008, 7-8.

${ }^{51}$ Steffen Hertog, "The Current Crisis and Lessons of the 1980s," Arab Reform Bulletin, July 2009.
} 
accompanied it and the subsequent pledge by the then ruler to enact reform and ratify the majority of the petition's demands. Demands for reform did not stop there, however, but continued at a lower intensity... before finally emerging into the light in 1992 in the form of two petitions. The most important of these petitions' demands was the election of a consultative council, appointed and tasked to draw up a permanent constitution. As a result of this, the signatories were punished with prison sentences, travel bans, the denial of their rights, and the threat to rescind their Qatari citizenship. ${ }^{52}$

Similar pressures arose in Saudi Arabia and Bahrain. The reign of King Saud (1953-64), in particular, witnessed prolonged periods of labor unrest emanating from oil workers protesting over conditions at Aramco (Arabian American Oil Company) camps in Saudi Arabia's Eastern Province. Major demonstrations began in October 1953 with a three-week strike by 13,000 workers in the oilfields around Dammam. The strike was suppressed violently, although pay and general conditions subsequently improved slightly. Three years later, a workers' protest during a visit by King Saud to Dhahran in June 1956 also was met with state violence, while a decade later, a wave of unrest broke out in Riyadh and other cities between November 1966 and February 1967. ${ }^{53}$ Neighboring Bahrain experienced a lengthy period of unrest between 1954 and 1956, which became fused with Arab nationalist and anti-British sentiments in the turbulent aftermath of the Suez Crisis in November that year. Oil workers were later involved heavily in a strike of BAPCO workers that paralyzed Bahrain in March 1965. This escalated rapidly into a general strike and the formulation of a platform calling for the right to hold political meetings and the release of all political prisoners, an end to the state of emergency in place since the 1956 troubles, and recognition of the right to form labor unions. ${ }^{54}$

The impact of oil on Bahrain and Kuwait had an additional, spatial dimension through the construction of "company towns" in Awali and Ahmadi respectively. These new "colonial" towns reshaped notions of urban space and patterns of lifestyle and consumption. Awali was

\footnotetext{
52 "Interview with Dr. Ali Khalifa Al Kuwari, Author of 'The People Want Reform...in Qatar, Too,"” Heinrich Boll Stiftung, March 3, 2014, http://www.lb.boell.org/web/52-1170.html.

53 Robert Vitalis, America's Kingdom: Mythmaking on the Saudi Oil Frontier (Stanford, CA: Stanford University Press, 2007), 218-24.

${ }^{54}$ Fred Halliday, Arabia without Sultans (London: Penguin Books, 2002), 443-46.
} 
constructed by BAPCO in 1937 and, over time, emerged as "an integral part of an inclusive urban public culture that was the unique creation of oil and embraced both indigenous and foreign workers" in Bahrain. ${ }^{55}$ Moreover, as Nelida Fuccaro has demonstrated, the oil boom in the 1950s had the effect of empowering a young and largely radical new generation of commercial workers and white-collar professionals who increasingly called into question the traditional governing practices of the ruling family and formed the vanguard of the ideological ferment centering around nationalism, communism, and $\mathrm{Ba}$ 'athism that came to characterize urban life in Manama. ${ }^{56}$ Ahmadi was built by the Kuwait Oil Company (KOC) in 1947 as part of a four-year Kuwait Building Plan intended to organize and rationalize the infrastructure needed to expand oil operations in the country. KOC commissioned James Wilson, a British architect who had worked as an assistant to Sir Edward Lutyens in the planning stages of New Delhi between 1913 and 1916. Wilson remained heavily influenced by his mentor and by the principles of the "garden city" design, and the result was a landscaped slice of greenery (and "regular garden competitions") set somewhat incongruously in the desert outside Kuwait City. ${ }^{57}$

\section{Limited Initial Impact of Globalization}

With oil having become central to the post-war world economy in the 1950 s and 1960 s, the oil revenues that cascaded into Gulf treasuries following the 1970s price shocks were magnified by the nationalization of the states' oil companies during the decade. In Kuwait, the state took control of the KOC in 1975 and five years later created the Kuwait Petroleum Corporation (KPC) as an umbrella organization, integrating the various upstream and downstream operations under government control. The newly independent government in Qatar established Qatar Petroleum in 1974 and nationalized all oil companies in 1977, while QatarGas was created in 1984 to produce liquefied natural gas for export to Japan. In Saudi Arabia, the nationalization of Aramco took place in stages between 1973, when the government first acquired a 25 percent share of the company, and 1980, when it took full control (and formally changed its name to

\footnotetext{
${ }^{55}$ Nelida Fuccaro, "Shaping the Urban Life of Oil in Bahrain: Consumerism, Leisure, and Public Communication in Manama and in the Oil Camps, 1932-1960s," Comparative Studies of South Asia, Africa and the Middle East 33, no. 1 (2013): 59 .

56 Ibid, 61.

${ }^{57}$ Reem Alissa, "The Oil Town of Ahmadi since 1946: From Colonial Town to Nostalgic City," Comparative Studies of South Asia, Africa and the Middle East 33, no. 1 (2013): 43-47.
} 
Saudi Aramco in 1988, when it also took over all remaining operational functions in the kingdom's oil and gas fields). The staggered process was notable for taking place in relative harmony with the four American concessionaires that made up Aramco, three of which (the now merged Exxon/Mobil and Chevron) continue to operate in Saudi Arabia today, albeit in a different capacity as providers of technical services. ${ }^{58}$ A similar harmony was apparent in Abu Dhabi, where Sheikh Zayed resisted full nationalization of the oil sector and maintained good relations with international oil companies as part of the broader modernization of the fledgling infrastructure of the UAE. ${ }^{59}$

Against this backdrop, a distinctive form of "Gulf capitalism" emerged as incoming oil revenues intersected with the rapid expansion of infrastructure and urban development. This grew out of the traditional "merchant family" business elites that predated the discovery of oil. Cut out by the ruling family/government from direct participation in the development of oil and gas resources, "Gulf capitalists" pursued business opportunities in other industries that were either derivative to the oil sector or were initiated with state assistance from accrued oil revenues. The most important of these opportunities initially were service and construction contracts granted to local companies by governments and foreign multinationals, either in the oil sector directly or for the infrastructural and industrial projects that formed the backbone of economic diversification programs. Many of these groups today are characterized by their continued involvement in these types of service and basic contracting activities, which remain the core of their business even as they have diversified and developed extensive interests in other sectors, such as retail and finance. ${ }^{60}$

The most prominent merchant families developed cross-border ties that spanned and far surpassed the Gulf states. Examples included business groups such as the Kanoo, al-Fardan, alZamil, and al-Qusaybi that drew together the Eastern Province of Saudi Arabia, Bahrain, and Qatar. International exposure initially was concentrated in the "agency" or franchising process, whereby brands needed a local partner in order to be able to set up shop within the Gulf, as well

\footnotetext{
${ }^{58}$ Adam Hanieh, Capitalism and Class in the Gulf Arab States (New York: Palgrave Macmillan, 2011 ), 69.

${ }^{59}$ Valerie Marcel, Oil Titans: National Oil Companies in the Middle East (London: Royal Institute of International Affairs, 2006), 28.

${ }^{60}$ Hanieh, Capitalism and Class, 69.
} 
as in the formation of joint ventures, particularly in the construction industry. ${ }^{61}$ Remittances from migrant laborers working in the Gulf also tied the economic fortunes of resource-poor states across the region to the oil-producing states. Countries in this "secondary-rentier" category included Egypt, Syria, Palestine, Jordan, and Yemen, where the impact on the local economies of North and South Yemen from the remittance flows from the 1.2 million Yemenis working in Saudi Arabia alone was most pronounced. ${ }^{62}$

And yet, despite these linkages and the flow of oil that made the Gulf indispensable to industrialized economies during the post-1945 period, the Gulf states, as with much of the broader Middle East region, were to a high degree untouched by the deeper processes of globalization as they accelerated in the 1970s and 1980s. This was due, in large part, to the fact that the oil sector operated largely in isolation from the wider economy and so shielded domestic markets from the full force of the international system; moreover, oil revenues acted as a cushion against international economic pressures, particularly after the 1970 s oil-price shocks. ${ }^{63}$ A paradox developed whereby both individuals and societies in the Gulf rapidly absorbed what John Fox et al. labeled "the material benefits of globalization," albeit in carefully controlled ways that limited and restricted the broader political or social penetration of global market forces. $^{64}$

An often-uneasy symbiosis thus developed between local and global patterns of change as they interacted and fed off each other. An example of the political ramifications was the evolution of Islamist narratives of resistance to globalization in the years immediately prior to the September 11, 2001, terror attacks in the United States. Other, less cathartic but still disruptive, manifestations of the tensions that occasionally surfaced came in the tangled webs of statebusiness relations when they intersected with international financial and corporate networks. Overlapping ties between the state and the new business elites produced frequently opaque

\footnotetext{
${ }^{61}$ J.E. Peterson, "Rulers, Merchants, and Shaykhs in Gulf Politics: The Function of Family Networks," in The Gulf Family: Kinship Policies and Modernity, ed., Alanoud Alsharekh (London: Saqi Books, 2007), 29.

${ }^{62}$ Gwenn Okruhlik and Patrick Conge, "National Autonomy, Labor Migration and Political Crisis: Yemen and Saudi Arabia," Middle East Journal 51, no. .4 (1997): 556.

${ }^{63}$ Ehteshami, Globalisation and Geopolitics in the Middle East, 110.

${ }^{64}$ John W. Fox, Nada Mourtada-Sabbah, and Mohammed al-Mutawa, "The Arab Gulf Region: Traditionalism Globalized or Globalization Traditionalized?," in Globalization and the Gulf, eds., John W. Fox, Nada MourtadaSabbah, and Mohammed al-Mutawa (London: Routledge, 2006), 3.
} 
governing arrangements. Members of ruling families often served as silent partners in business enterprises or became major business figures in their own right. The line between state funds and private capital was blurred further by the representation-usually in a "private capacity" - of ruling family members on company boards. ${ }^{65}$ Additional characteristics of state-business ties in Gulf states included allocation by the states of multinational franchising to local groups linked to major merchant families, as well as the importance of "brokers" and "gatekeepers" who controlled and provided direct access to prominent decision-makers in the state apparatus. It has been taken for granted by many observers of Gulf business patterns that senior figures in ruling families participate actively in business decisions, with key individuals frequently being singled out for their allegedly rapacious involvement in commercial affairs. ${ }^{66}$

\section{Conclusion}

This paper has documented the linkages between the Gulf states and the global economy as they evolved during the 20th century. Between the 1930s and the 1950s, the extraction and export of oil transformed the political economy of the small coastal sheikhdoms and of Saudi Arabia and dramatically reconfigured state-society relations within the newly independent polities. While the network of political and security ties with the West distinguished the Gulf states from other post-colonial settings and largely shielded them from revolutionary upheaval, the phases of engagement between the Gulf and regional and international partners were not static. Rather, they ebbed and flowed as the century progressed before reaching a watershed moment in 199091 with the Iraqi invasion of Kuwait on August 2, 1990, and the subsequent liberation of Kuwait by an international-led coalition assembled by President George H.W. Bush and Secretary of State James A. Baker III in January-February 1991. This occurred in a moment of profound change in the international system and coincided with the end of the Cold War and the acceleration of global political and economic change. Over the two decades that followed, the links with the international system would broaden and deepen as the Gulf states became more

\footnotetext{
${ }^{65}$ Peterson, "Rulers, Merchants, and Shaykhs in Gulf Politics," 24.

${ }^{66}$ Author observations and interviews in Bahrain (December 2008 and October 2009), Dubai (December 2011), Abu Dhabi (May 2012), Kuwait (December 2011 and March 2013), Qatar (May 2013 and February 2015), and Saudi Arabia (March and December 2014).
} 
The Political Economy of Arab Gulf States

active participants in the global economy in ways that moved decisively beyond the hydrocarbons sector. 